Shifting Edenic Codes: On Two Exotic Visions of the Golden Age in the Late Eighteenth Century

\title{
Vladimir Kapor
}

The English and French exploration of the South Pacific in the second half of the eighteenth century ${ }^{\mathrm{i}}$ led to an increased vogue for exotic trends in Western literature and added a new element to the repertoire of stock exotic tropes - that of tropical islands in the South Seas. If the insular thematic is not a complete novelty in the eighteenth century, the travelogues of Cook and particularly Bougainville endow the encounter with the inhabitants of these isolated islands with a new and more seductive imagery of the far-flung. As Richard Grove remarks in his study on Green Imperialism: "Prior to 1768 desert-island literature had tended to contemplate isolated communities of either men or (less frequently) women but had rarely put them together. This was changed radically by the Bougainville expedition and the incorporation of a newly constructed sexuality as part of the same return to nature which underlay environmentalism." ${ }^{\text {ii }}$ This statement is particularly relevant to the Pacific area, where imperial expansion "has been imagined as sexual event" from the outset, according to Lee Wallace. ${ }^{\text {iii }}$

In Europe and beyond, Rousseau's influential theories on the "state of nature" and classical heritage contributed to the shaping of an idyllic topos of an exotic golden age ${ }^{\mathrm{iv}}$, usually sheltered from nefarious external influences by the remoteness and closed-off nature of its insular setting. However stereotypical and self-explanatory this concept of an Edenic island at the opposite end of the world may seem with the hindsight of over two centuries, at 
the end of the eighteenth century it allowed for quite contradictory esthetic, moral and philosophical investments. Similarly, the impact its variations have had on the Western imagination is more manifold and less straightforward then usually suspected, as will be demonstrated by two strongly contrasting cases among late eighteenth-century French writers.

Indeed, the depiction of Tahiti in Bougainville’s travelogue of his journey around the world and the portrayal of the small community formed by the two protagonists' families in Bernardin de Saint-Pierre's pastoral novel Paul et Virginie set on Mauritius, even though drawing on the same pool of themes and images, offer two emphatically dissimilar visions. Even though both Edenic ${ }^{\mathrm{v}}$ visions position the "state of nature", at the heart of contemporary philosophical debates, as the privileged state of human society, not just an origin but an ideal, the overtones of their respective philosophical investments lead to a series of sharp differences on more than one level. The term "philosophical" may seem inappropriate with regard to Paul et Virginie, often perceived as a sentimental novel or a "pastoral”, as its author referred to it on several occasions. It should be noted, however, that this narrative initially appeared in the fourth volume of Studies of Nature, under the title Nature's Portrait, and was subsequently described by the author as an "application of the laws" observed elsewhere in this wide-ranging and highly teleological study. ${ }^{\mathrm{vi}}$ The novel could therefore be regarded as a “roman à thèse”, allowing us to argue that, from a conceptual perspective, these two visions of a hypothetical golden age illustrate divergent viewpoints on the moral implications of the state of (human) nature, specifically conflicting attitudes towards marriage and sexual liberty.

The most striking difference lies, indeed, in the manner in which issues of morality and virtue are addressed within the two Edenic codes: the sexual liberation of the Polynesian islanders (which was, though, no match for the debauchery of Bougainville’s crew) stands in sharp contrast to the innocence and chastity of Bernardin's young protagonists, whose way of life is clearly inspired by the utopian micro-society of Clarens described in Rousseau's La 
Nouvelle Héloïse. ${ }^{\text {vii }}$ The much debated thesis of Bernardin de Saint-Pierre’s novel is stated in rather ambiguous wording, which does not allow us to determine precisely whether the relation between nature and virtue is one of inclusion (of virtue in Nature), or rather conjunction (of two incommensurable terms): “[...] notre bonheur consiste à vivre suivant la nature et la vertu." ${ }^{\text {viii }}$ [our happiness consists in living according to Nature and virtue.] (PV, 37). In addition, the idyllic part of the novel, relating the early youth of Paul and Virginie, ends precisely with the awakening of sensuality in the adolescent heroine. ${ }^{\mathrm{ix}}$ This hints at another perceptible difference, concerning narrative outcomes. Whereas Bougainville’s travelogue tends to focus on the crew's perception of their encounter with the natives, whose community and ways of life are described as petrified and sempiternal (thus ignoring the consequences of the advent of Northern navigators in the South), Bernardin embraces the point of view of a settler narrator and shifts the focus precisely to the nefarious influences of agents and factors alien to the isolated micro-community that propel the narrative to its tragic denouement. $^{\mathrm{x}}$

It is important to underline from the outset that the shifting of Edenic codes perceptible in these two works published within less than twenty years of each other (1771 and 1788 respectively) was no accident. In many ways Bernardin de Saint-Pierre proposes an explicit critique of Bougainvillean naiveté. In a recent article, Malcolm Cook has reproduced a letter by Bernardin de Saint-Pierre that relates his encounter with Bougainville and the crew of the Boudeuse on Mauritius, before the publication of the navigator's travelogue. ${ }^{\mathrm{x}}$ The account of Bougainville’s stay at Tahiti, as recorded by Bernardin, contains many episodes and details found in the navigator's subsequently published work, such as the visit some Tahitian women made to Bougainville’s boat, a description of plants and animals encountered on the island and a thesis on the "two races" of Tahiti. All this provides irrefutable evidence of Bernardin de Saint-Pierre’s first-hand familiarity with Bougainville’s Tahitian mirage. It is 
uncertain, however, whether Bougainville or perhaps his ribald crew are hinted at in Bernardin's statement of intent included in the Preface to the original 1788 edition of the novel, but Bernardin's will to innovate with regard to the traditional manner of depicting islands in the South Seas is obvious:

“Je sais que des voyageurs pleins de gout nous ont donné des descriptions enchantées de plusieurs îles de la mer du Sud; mais les moeurs de leurs habitants, et encore plus celles des Européens qui y abordent, en gâtent souvent le paysage. J’ai désiré réunir à la beauté de la nature entre les tropiques la beauté d’une petite société (PV, 1989, CLVII).

[I know that certain travelers who are also men of taste have given us enchanting descriptions of several islands of the southern ocean; but the manners of their inhabitants, and still more those of the Europeans who land there are often a blot on the landscape. I wished to join to the beauty of nature between the tropics the moral beauty of a little society.]” (PV, 1982, 37)

Philibert Commerson, the medical naturalist of the Bougainville expedition, disembarked from the Boudeuse in Mauritius. The Commander relieved him of his obligations and gave him permission to stay in the colony. Commerson, who kept a personal diary of the expedition, may have played a significant mediating role in the process of disseminating the Tahitian narrative on Mauritius and beyond, as he shared Bougainville's enchantment with the islanders' unashamed sexual displays, but displaced Bougainville’s "New Cythera” by the term "Utopia”, a discourse better fitted to Bernardin de Saint-Pierre’s purpose. Unlike Bougainville, Commerson was interested in the description of horticultural details on the fruit trees of Tahiti and was toying with the idea of creating Edenic botanic gardens upon entering Pierre Poivre’s employment on Mauritius ${ }^{\mathrm{xii}}$, gardens not dissimilar to those planted by Bernardin's fictional members of his micro-community on the Ile de France. 
Commerson and Bernardin de Saint-Pierre, who was appointed head engineer on the island, were both members of the social circle formed around Pierre Poivre, physiocrat and colonial administrator of Mauritius. They all shared pioneer concerns about environmental issues, but also established a link between biological and social habitat, which resulted in resonances perceived between moral and physical categories. They regarded the island as a laboratory for conducting all sorts of real or fictional experiments, social as well as ecological. Thus Bernardin's novel is deeply embedded in experimental, scientific discourse.

We can draw two inferences from Bernardin de Saint-Pierre’s involvement with Poivre's social circle. Firstly, through his encounters with both Bougainville and Commerson, he must have been well acquainted - avant la lettre - with Bougainville's instantly mythified Tahitian encounters. Secondly, it is fair to argue that his vision of a utopian micro-society set in Mauritius was intended to stand in contrast to the dominant literary mode of depicting exotic islands, with sustained experimental overtones. By the same token, it challenged the contemporary political and philosophical debates on the structure of an ideal society, which were kindled by Bougainville’s account of Tahiti.

Both Edenic codes have unquestionably had a considerable impact on the Western imagination, yet their respective legacies may seem puzzling and somewhat paradoxical. Bougainville's travelogue based on a real journey was to become the origin of the "Tahitian mirage”, which would give rise to more than one abstract philosophical argument in favor of a society based on "natural laws", such as developed in the writings of Diderot, Bricaire de La Dixmerie or Madame de Monbart ${ }^{\text {xiii }}$; it would also prompt the link between exoticism and eroticism, long-cemented since, particularly in the sphere of popular culture. ${ }^{\text {xiv }}$ Bernardin was, on the other hand, praised by the generation of French Romantic and Realist writers as the inventor of local colour and exoticism in French fiction, notably for the plasticity and 
precision of his exotic fictional setting. In the introduction to his German travelogue published under the title Lorely, Gérard de Nerval observes of travel writers of the past: "Il est donc possible qu'on voyage sans regarder, ou bien qu'on regarde sans voir. Il a fallu que Bernardin de Saint-Pierre vît les étranges paysages de l’Amérique et des Indes, pour créer en quelque sorte la couleur locale, dont on a tant abusé depuis. [It is therefore possible to travel without looking, or to look without seeing. It was necessary for Bernardin de Saint-Pierre to see the strange landscapes of America and the Indies, to create, in a way, local colour, which has since been so abused.]” ${ }^{x v}$

It would, of course, be unfair to reduce Bernardin's influence exclusively to his descriptive craftsmanship, but from the perspective of the evolution of the imagery of South Seas and exoticism this trait appears as most salient. ${ }^{\text {xvi }}$

In an attempt to account for this unexpected code-shifting, an effort must be made to bracket off the layers of clichés and stereotypical images associated with the South Seas that blur and distort our perspective, as well as the series of philosophical debates and glosses the two works have sparked, and return to the two texts we have identified as imagegenerating. ${ }^{\text {xvii }}$ By placing the two texts at the centre of my argument, I will strive to examine which textual elements have been dominant in the shaping of Western imagery of exotic islands, and which mechanisms have contributed to the singling out of these elements. In doing so, I will also an attempt to render explicit the differences between two identified Edenic codes and reflect on the working of collective imagery with a view to accounting for the somewhat paradoxical fate of the two works.

The first major code difference that contributes to the shaping of the two conflicting visions of the golden age is that of genre: Bougainville's narrative is a travelogue and thus falls within the category of factual/non-fictional genres, whereas Bernardin defines his work as a "novel" or "pastoral”. Two observations should, however, be made about this distinction. 
Bougainville initially penned his impressions in the captain's log, the Pacific journal, which has now been made available by Emile Taillemite ${ }^{\text {xviii }}$ (translated into English by John Dunmore). ${ }^{\text {ix }}$ A comparative study of the travelogue and the journal demonstrates notable stylistic labours by Bougainville; morever, the degree to which the initial log entry text was edited suggests that events described in the travelogue should not be regarded as hard fact, as the modifications tend to add a fictional note, transforming the text into a more coherent narrative with additional philosophical reflections on Tahitian society. On the whole, however, it can be argued that Bougainville’s text conforms to the formal requirements of the travelogue genre, with inevitable nautical observations and unmistakable utilitarian and imperialist overtones in the description of the newly discovered territories and potential colonies.

As regards Bernardin de Saint-Pierre, it should be mentioned that his first published work, Voyage à l'Ile de France, was also a travelogue in which the description of Mauritius acquires a quite negative slant, which in turn emphasizes the fictional, idealized character of the utopian vision found later in Paul et Virginie. The fictional text integrates the materials presented in the travelogue under encyclopedic headings such as "Trees and water plants", "Animals native to the island" and "On soil and natural products", whilst adopting a perspective that is more suggestive than informative.

Accordingly, confronted with the challenge of representing the exotic, the two authors negotiate quite dissimilar writing strategies, in spite of certain similarities of style. These stylistic convergences stem from the then dominant code of classicist poetics, which pervades both works and accounts, for instance, for the quotations from Virgil and Horace and imagery drawing on Greco-Roman mythology and tradition.

In Paul et Virginie, for example, Bernardin uses an antique simile to describe the two children hiding from the rain under Virginie’s skirt: “Ces deux têtes charmantes renfermées 
sous ce jupon bouffant me rappelèrent les enfants de Léda enclos dans la meme coquille.” (PV, 1989, 90) [The sight of these two pretty heads encircled by the billowing petticoat brought to my mind the children of Leda, enclosed in the same shell.] (PV, 1982, 47)

The following simile is also clearly inspired by the Homeric style:“ Comme le soleil fond et précipite un rocher de glace du sommet des Apennins, ainsi tomba la colère impétueuse de ce jeune homme à la voix de l'objet aimé.”(PV, 1989,153) [As the sun melts a great rock of ice on the summit of the Apennines and sends it rushing down the slope, so did the young man's impetuous anger subside at the voice of his beloved.](PV, 1982, 87)

The same repertoire of imagery is found at work in Bougainville, who portrays the stature of Tahitians in the following terms: "pour peindre Hercule et Mars, on ne trouvera nulle part d'aussi beaux modèles.”xx [in order to paint a Hercules or a Mars, one could no where find such beautiful models.] (Bougainville, 1772, 249)

Another example of antique simile can be found in the famous passage: "La jeune fille laissa tomber négligamment un pagne qui la couvrait, et parut aux yeux de tous telle que Vénus se fit voir au berger phrygien: elle en avait la forme céleste. (Bougainville, 1999, 100) [The girl carelessly dropt a cloth which covered her and appeared to the eyes of all beholders such as Venus shewed herself to Phrygian shepherd, having, indeed, the celestial form of that goddess”. (Bougainville, 1772, 218-19)

One of the main stylistic differences is perceptible, however, with regard to naming the exotic. Notwithstanding the notionally scientific and exploratory character of his expedition, Bougainville is reluctant to employ neologisms or foreign words, while the technical vocabulary he uses is restricted to navigation terminology. When he does venture to garnish his text with a few key words of the Tahitian language, these are systematically singled out by their font (always in italics), transcribed phonetically according to the rules of French spelling, and immediately translated or paraphrased through their French equivalents: 
“All these people came crying out tayo which means friend” (217), “Tata-einou, vile men” (270), “a Taoua, i.e. a doctor or inferior priest” (271. All quotes from Bougainville, 1772).

On the whole, it can be argued that Bougainville's discourse demonstrates a preference for terms that are abstract and generic, and lacking in precision, while the exotic culture itself is rendered through the medium of common French vocabulary and concepts, relying on the extensive use of catachresis, synecdoche and periphrasis. Instead of introducing foreign words and concepts into French culture, and thus annexing the newly proclaimed French colony to the existing territory and adding a new flavour to metropolitan French culture, Bougainville is more inclined to translate and render the alien culture in familiar terms in an effort to assimilate it, careless of the possible distortions, simplifications and misconceptions this may lead to. This is probably one of the main reasons why the Tahitian mirage so easily took root and finally supplanted his actual account of the island.

The social hierarchy of Tahiti is, for instance, explained in completely European terms through a series of catachreses: “kings”/“grandees"/”servants” (dressed in "liveries” moreover)/"slaves" and even "the chief of this district". The synecdoches we are referring to rely on the similarity between two objects in terms of types, but bear, in this exotic discourse, tangible evidence of conceptual coupling, as the unfamiliar entity of the exotic culture is described using its familiar analogon: “a kind of drum” (257), "kind of castanets” (247. Both quotes from Bougainville, 1772).

This approximation results in a lack of precision and a highly domesticated exotic, misleadingly guiding the reader towards images of familiar objects and concepts. Bougainville thus represents Tahiti as seen by a French philosophe-navigator of the Enlightenment era, written in the first person (of both singular and plural - a hallmark of the captain's log genre), and catering for an audience of his enlightened fellowmen. To paraphrase Edward Said, it is a reconstruction of the South in terms of Bougainville's 
imaginative vision, nourished by Northern (and specifically French) philosophical and social concerns.

Bernardin, on the other hand, deplores explicitly the lack of precision in the descriptions found in travelogues and laments this in his Voyage à l'Ile de France:

“L’art de rendre la nature est si nouveau que les termes mêmes n’en sont pas inventés. Essayez de faire la description d'une montagne de manière à la faire reconnaître : quand vous aurez parlé de la base, des flancs et du sommet, vous aurez tout dit. Mais que de variété dans ces formes bombées, arrondies, allongées, aplaties, cavées, etc ! Vous ne trouvez que des périphrases. C’est la même difficulté pour les plaines et les vallons [...].Il n’est donc pas étonnant que les voyageurs rendent si mal les objets naturels. S’ils vous dépeignent un pays, vous y voyez des villes, des fleuves et des montagnes, mais leurs descriptions sont arides comme des cartes géographique : l'Indoustan ressemble à l'Europe. La physionomie n’y est pas." ${ }^{\mathrm{xxi}}$

[The art of conveying nature is so new that the terms have not even been invented. Try to describe a mountain so as to make it recognizable: when you have talked about its base, its flanks, and the summit, you have said it all. But what varieties in these curved, round, long, flat, hollowed-out forms etc. You can only find roundabout phrases. The same goes for plains and valleys. [...] It is not surprising, then, that travellers render natural objects so poorly. If they paint a country, you will see towns, rivers, mountains; but their descriptions are arid like geographical maps: India is no different to Europe. The peculiar characteristics are not there. $]^{\mathrm{xxi}}$

This characteristic passage reveals the concerns and priorities which are later to be found in Paul et Virginie. The interest in environmental issues and natural history (which he shares with Commerson) leads him to devote as much (if not more) attention to the 
description of the Eden-like garden and tropical nature that surrounds the dwellings of the protagonists as to the explanation of the tacit principles and laws that govern his idyllic exotic community. ${ }^{\text {xxiii } I n}$ order to achieve this, he discards the generally accepted form of first person narrative (typical for travelogues), and opts for a different narrative technique.

Delegating the narrative voice to a secondary narrator, an old settler, familiar with two cultural codes - the French code of the main narrator and that of the Creole community of colonists - enables him to negotiate the process of representing the exotic with a greater deal of code switching which does not jeopardize the verisimilitude of the narrative. This can be seen, for instance, in the free use of vernacular names for plants and animals, and the authentic topography of the island, exotic by its "motivated" character, atypical for the codes of Western toponymy: “le Morne de la Découverte” - Discovery Hill, “L’Embrasure”, “La Montagne des Trois-Mamelles” - The Three Paps. ${ }^{\text {xxiv }}$

The story of Paul and Virginie is thus narrated from the first-person point of view of a settler (who appears briefly at the beginning and the very end of the novel) characterized by the possession of an in-depth knowledge of the milieu, as well as of the cultural codes of the addressee. This enables Bernardin not only to minimize the distortions and misinterpretations which the Eurocentric imperial gaze entails, but also to impute all non-metropolitan alien elements found in the representation of Mauritius to the mixed Creole cultural identity of the narrator. The embedded narrative formula with a settler figure for a secondary narrator enacted in Paul et Virginie was to have a rich posterity in exotic literary fiction, and was to be used with success by authors such as Chateaubriand (Atala) or Théophile Gautier (Le Roman de la momie).

The use of description provides an even sharper contrast between the styles of the two authors: Bougainville’s descriptions are sketchy and never list and chart the plant and animal species encountered: 
“Le pays bas où nous étions n'est couvert que d'arbres fruitiers et d'une espèce de bois plein de gomme et de peu de consistence (Bougainville, 1999, 105) [the low country where we were, was covered only with fruit trees and a kind of wood full of gum, and of little consistence]” (Bougainville, 1772, 226 emphasis mine).

The collective term "fruit trees" suggests a multitude of species but presents them as a whole without an effort to particularize, while an unknown tree species is described through a synecdoche ("kind of wood”), from a vaguely utilitarian perspective: “full of gum” (potential isolator or wood polish), "of little consistence" (hence not suitable for wood-carving - the rest of the sentence confirms this interpretation: "the hard wood grows upon the mountains").

A stylistic feature typical to his descriptive technique is the use of generic words, which put an abrupt end to incipient taxonomies: "Ils ont bien aussi autour de leurs maisons des espèces de potagers garnis de giraumons, de patates, d'ignames, et d'autres racines” (Bougainville, 1999, 106-107) [They have likewise around their houses a kind of kitchen gardens in which they plant an eatable hibiscus or okra, potatoes, yams and other roots] (Bougainville, 1772, 229 emphasis mine).

Bernardin de Saint-Pierre, on the other hand, refines and extends descriptive technique through his graphic and lush depiction of tropical flora, obtained by finely honed cadenced sentences replete with vernacular names embedded in chains of alliterations and assonances. It was the evocative potential and graphic character of such descriptive devices that earned him the praise of the following generation of Romantic and Realistic writers.

This contrast can be well illustrated by the variations that the topos of landscape description, identified as locus amoenus or pleasance by Ernst-Robert Curtius ${ }^{\mathrm{xxv}}$ takes on in their writings. Bougainville notes of his first inland excursions 
“J’ai plusieurs fois été, moi second ou troisième, me promener dans l'intérieur. Je me croyais transporté dans le jardin d’Eden: nous parcourions une plaine de gazon, couverte de beaux arbres fruitiers et coupée de petites rivières qui entretiennent une fraîcheur délicieuse, sans aucun des inconvénients qu'entraîne l'humidité. Un people heureux y jouit des trésors que la nature verse à pleines mains sur lui. [...] partout nous voyions régner l’hospitalité, le repos, une joie douce et toutes les apparences du bonheur. (Bougainville, 1999, 106)

[I have often, in company with only one or two of our people, been out walking in the interior parts of the isle. I thought I was transported into the garden of Eden; we crossed a turf covered with fine fruit-trees, and intersected by little rivulets which keep up a pleasant coolness in the air, without any of those inconveniences which humidity occasions. A numerous people there enjoy the blessing which nature showers literally down upon them. [...] every where we found hospitality, ease, innocent joy and every appearance of happiness amongst them.]” (Bougainville, 1772, 228-29)

All the conventional elements of the topos are present, but are confined to a single generic term: "fruit-trees" designate the abundant nature, while "rivulets" stand for the aquatic element. Bougainville focuses on the impact of this beneficent natural surrounding to the islanders and readily drifts towards moral categories and considerations on Tahitian society: “hospitality, ease, innocent joy and every appearance of happiness”.

In Paul et Virginie, in contrast, Bernardin de Saint-Pierre materializes the locus amoenus topos in the garden planted by the young Paul in the enclosure surrounding the two families' huts:

“Paul, à l'âge de douze ans, plus robuste et plus intelligent que les Européens à quinze, avait embelli ce que le Noir Domingue ne faisait que cultiver. Il allait avec lui dans les bois voisins déraciner de jeunes plants de citronniers, d'orangers, de tamarins dont la tête ronde est 
d'un si beau vert, et d'attiers dont le fruit est plein d'une crème sucrée qui a le parfum de la fleur d'orange: il plantait ces arbres déjà grands autour de cette enceinte. Il y avait semé des graines d'arbres qui dès la seconde année portent des fleurs ou des fruits, tels que l'agathis, où pendent tout autour, comme les cristaux d'un lustre, de longues grappes de fleurs blanches; le lilas de Perse, qui élève droit en l'air ses girandoles gris de lin; le papayer, dont le tronc sans branches, formé en colonne hérissée de melons verts, porte un chapiteau de larges feuilles semblables à celle du figuier.

Il y avait planté encore des pépins et des noyaux de badamiers, de manguiers, d'avocats, de goyaviers, de jaques et de jameroses. La plupart de ces arbres donnaient déjà à leur jeune maître de l'ombrage et des fruits. [...] Diverses espèces d'aloès, la raquette chargée de fleurs jaunes fouettées de rouge, les cierges épineux, s'élevaient sur les têtes noires des roches, et semblaient vouloir atteindre aux longues lianes, chargées de fleurs bleues ou écarlates, qui pendaient çà et là le long des escarpements de la montagne.” (PV, 1989, 108110)

[At twelve years of age Paul was more robust and intelligent than Europeans at fifteen, and where the Negro Domingue had merely cultivated, he had beautified. He went with him to the neighbouring woods to uproot young lemon- and orange-trees, tamarinds whose round tops are of such a lovely green, and custard-apple trees whose fruit contains a sweet cream with the fragrance of orange-blossoms. He set these trees, which had already grown quite tall, around the perimeter of their enclosure, where he had already planted the seeds of those trees that flower or fruit in their second year: agathis whose long bunches of white flowers hang down in a circle like the crystals of a chandelier; the Persian lilac whose clusters of blossoms, the colour of unbleached linen, rise straight into the air; and the papaw whose trunk bristles 
with green melons instead of branches and rises to a capital of broad leaves like those of the fig-tree.

Besides these, he had planted the pips and kernels of myrobalans, mangoes, avocados, guavas, jack-fruits and jambos, most of which had already grown into trees and were affording their young master fruit and shade. [...] Various species of aloes - some with racket-shaped leaves heavy with yellow flowers splashed with red, others like tall, spiny candles - grew on the black tops of the rocks, from which they rose as if trying to reach the long creepers covered with blue or scarlet flowers which hung here and there along the steep slopes of the mountain.]” (PV, 1982, 59)

The syntax of the whole passage is underpinned by a recurrent rhythmical pattern; the organization of the predicates in a sentence is threefold: lemon- and orange-trees - tamarinds - custard-apple trees; agathis - Persian lilac - papaw; or double threefold: myrobalans, mangoes, avocados, guavas, jack-fruits and jambos (the unity of the sequence being cemented, moreover, in this last example by a strong assonance in “a” which John Donovan's translation renders very faithfully). Such a disposition assimilates Bernardin’s descriptive sequences to the prose poem genre, thus transcending the established generic partitions of preRomantic prose. If the technical botanic terms may seem to jeopardize the readability of the text, their meaning can be traced to an authorial intertext. Indeed, most plants mentioned in Paul et Virginie were first described in Bernardin’s first published work, Voyage à l’Ile de France. ${ }^{\text {xxvi }}$ With the aid of this valuable document, we come to realize that the rhythmical patterns that command the grouping of different plants correspond not only to phonetic principles but also to an upwards spatial movement along the vertical axis covering different vegetation layers from bushes, fruit-bearing trees, all the way up to the creepers, sketching the contours of the perfect geometric shape of an amphitheatre. If the classification of the exotic 
into types, which begins with the act of naming, is one of the main techniques for reconstructing the alien, the principles that govern these classifications in Paul et Virginie (but not in Voyage à l'Ile de France, penned by an officier du roi, as stated on the cover page), are more aesthetic and providentialist than overtly imperialist and utilitarian. ${ }^{\text {xvii }}$

Indeed, descriptions of the exotic setting constructed in this way illustrate the perfect harmony of nature, typical of Bernardin's teleological world-view. Guided by the hand of Providence, the self-taught landscape gardener can hence arrange the plants "according to his own plan” without straying from Nature’s, "with her as a guide”, since nature’s purpose is to cater for man's needs. In the eighteenth century this descriptive method is seldom practiced among travel writers. An exception can be found with Joseph Banks, the botanist of the Cook expedition, whose plant description sometimes take up quite poetic overtones, despite the overtly utilitarian perspective which gives the general tone to his writings (Banks never omits, for instance, to underline the potential nutritional or "antescorbutick virtues" of a species described). In Banks's description of the Island of Savu, for example, aesthetic concerns are quite prominent, with reference to categories such as proportion:

"The appearance of the Island especialy on the windward side where we first made it was allowd by us all to equal in beauty if not excel any thing we had seen [...] the gentle sloping of the hills which were cleard quite to the top and planted in every part with thick groves of the fan Palm, besides woods almost of Coca nut trees and Arecas which grew near the sea side, filld the eye so completely that it hardly lookd for or missd the verdure of the earth, a circumstance seldom seen in any perfection so near the line. How beautifull it must appear when coverd with its springing crop of Maize, Millet, Indigo \&c. which covers almost every foot of ground in the cultivated parts of the Island imagination can hardly conceive: the verdure of Europe set of by the stately pillars of India - Palms I mean, especially the Fan palm which for streightness and proportion both of the stem to itself and the head to the stem 
far excels all the Palms that I have seen - requires a poetical imagination to describe and mind not unacquainted with such sights to conceive.”xxviii

Passages such as this one are, however, scarce and cannot be regarded as a typical descriptive feature of Bank’s travel writing. ${ }^{\text {xxix }}$

It is also important to emphasize at this point that unlike Rousseau or Bougainville, Bernardin's union of the "beauty of nature between the tropics" and "the moral beauty of a little society” heavily invests the stylistic dimension of his writing, as the analyzed passage tries to demonstrate. Bernardin himself insisted on the organic link between style and thought, and wrote as a response to newspaper criticism that had granted him the talent for depicting nature, despite claiming that there were numerous other shortcomings in his novel: "le style n’est ni la décoration ni l’habit de la pensée ... il en est l'expression. Le style est à la pensée, non ce que l'habit, mais ce que les muscles sont au corps. L'habit voile le corps, les muscles le montrent." (PV, 1989, CLXVI) [ style is neither the ornament nor the clothing of thought, it is its expression. Style stands to thought, not as clothing, but rather as muscles do to the body. Clothing conceals the body, muscles reveal it] (translation mine).

Following this stylistic analysis, it is fair to argue that Bougainville's account of his call at Tahiti was predetermined to become a philosophical abstraction, through its use of writing strategies lacking the particular and the local, as well as through the navigator's focus on the social structure issues that were at the heart of contemporary philosophical debates. A passage from his captain's log, omitted in the published version of the travelogue, renders this ambition quite explicit:

“Législateurs et philosophes, venez voir ici tout établi ce que votre imagination n’a pu meme rêver. Un people nombreux, compose de beaux homes et de jolies femmes, vivant ensemble
2ل) 10: I know banks's orthography is peculiar but can you check 'hadly' for example. I don't think we need 'sic' though all the same. 
dans l'abondance et la santé, avec toutes les marques de la plus grande union, connoissant assew le mien et le tien pour qu'il y ait cette distinction dans les rangs nécessaire au bon ordre, ne le connoissant pas assez pour qu'il y ait des pauvres et des fripons [...] (Bougainville et ses compagnons autour du monde, 326-27)

[ Lawmakers and philosophers, come and see here all that your imagination has not been able even to dream up. A large population, made up of handsome men and pretty women, living together in abundance and good health, with every indication of the greatest amity, sufficiently aware of what belongs to the one and the other for there to be that degree of difference in rank that is necessary for good order, not knowing enough about it for there to be any rogues or poor people...] (Pacific Journal, 72)

It is therefore plausible to assume that Bougainville viewed Tahiti with a heavy philosophical investment, through an array of pre-existing concepts such as the "Noble Savage" or "state of nature" and reconstructed it accordingly, thus in turn shaping the abstract Tahitian mirage. Furthermore, the selective readings of Bougainville's travelogue tend to abstract the last part of the narrative in which Aotourou's account helps debunk more than one initial misconception about Tahitian culture ${ }^{\mathrm{xxx}}$. However, the feature of Bougainvillian vision of exotic paradise that posterity was to retain is eroticism (on a faraway tropical island whose contours are rather blurred), devoid of its philosophical background and far from debates on the perfect state of human nature. ${ }^{\mathrm{xxxi}}$

As for Bernardin de Saint-Pierre, the legacy of his prose seems to have been determined by a similar reduction mechanism. The teleological backdrop to Paul et Virginie (and to his acclaimed descriptive techniques) was soon to be abstracted, along with the novel's experimental and illustrative character within the framework of Studies of Nature. In 
this case, it is possible to talk of the philosophical disinvestment of writing devices, which led to the weakening of the novel's utopian overtones, giving way to appraisal of the precision and graphic character of his descriptions. To borrow Northrop Frye's terminology in his theory of "modes"xxxii , the exotic setting partaking of the idyllic-pastoral atmosphere which characterizes the first part of the novel, typical of the romantic comic mode according to Frye, is ultimately displaced by the realistic overtones of the low mimetic tragic mode.

In this manner, a most unexpected code shifting occurs: a real journey related through a non-fictional genre leads to erotically-tinted philosophical abstractions, while an idealized, utopian vision of a fictional and experimental micro-society gives rise to the realistic tendencies in exotic fiction and travelogues. Before the elements of the two conflicting Edenic codes were to be absorbed by Northern/Western imagery, they needed to go through a process of philosophical disinvestment, and modal displacement (Frye), which was to select, isolate and irreversibly sever them from their original context.

It is interesting to note that the initial contrast between these two influential visions of a far-flung golden age has weakened with time, through the same mechanism. This merging can be perceived notably through the connection and partial fusion of the lush descriptions of exotic setting and eroticism, amounting to the somewhat paradoxical formula: sexual encounters in the Garden of Eden. This uncanny combination became a constant element of exotic prose in Gautier, Flaubert, Melville (aipee, Omoo), and attained its peak in the prose of Pierre Loti where it is best exemplified in Rarahu (Le Mariage de Loti) set in Tahiti. From the late nineteenth century it has become part of the current stock elements of contemporary paraliterary genres such as pulp-fiction romance or the spy novel. ${ }^{\text {xxxiii }}$

The fate of the two conflicting exotic visions of the golden age provides a most revealing illustration of mechanisms through which social imagery is shaped and constructed. For if its elements are initially singled out according to their sympathy with the 
preoccupations of a period, like eroticism in an era in which sexuality and gender relations were in the process of being renegotiated, or the art of describing nature at the dawn of Romanticism in France, once isolated, they start a life of their own, regardless of their original generic, thematic or narrative context, freely transcending genres, aesthetic movements or philosophical orientations. The example of exotic Edens also underlines the importance of an understanding of this evolutionary, combinatorial process in any study of the impact which travel to Southern seas has had on the Northern imagination, or in the investigation of exoticism as a literary and artistic phenomenon. As we have tried to demonstrate, the exploratory path through collective imagery is often strewn with the most unsuspected lineage and figures, as we leave both Tahiti and Mauritius and enter the realm of what has been commonly referred to, since Roland Barthes, as popular mythology.

\footnotetext{
${ }^{\mathrm{i}}$ The first expeditions in the South Pacific were those of Magellan and the Dutch navigators in the sixteenth century. However the most memorable journeys to this part of the globe, leading to a detailed charting of the South Pacific territory, were recorded by English and French expeditions in the eighteenth century. In the 1760s King George III of England gave orders to explore the South-Sea and Polar regions. Prompted by this initiative, expeditions lead by Byron, Wallis, Carteret and Cook left some of the most influential accounts of this part of the globe. On the initiative of the Duke de Choiseul, Louis XV of France lent his support to the expeditions of Bougainville and Lapérouse in an attempt to rival the British. For a detailed account, Bernard Smith, European Vision and the South Pacific, 1768-1850 (Oxford: Oxford Univ. Press, 1960).

ii Richard Grove, Green Imperialism: Colonial Expansion, Tropical Islands Edens and the Origins of Environmentalism, 1600-1860 (Cambridge: Cambridge Univ. Press, 1995), 253.
} 
${ }^{\text {iii }}$ Lee Wallace, Sexual encounters. Pacific Texts, Modern Sexualities (Ithaca and London: Cornell Univ. Press, 2003), 1.

iv The components of the exotic island representations found in the two works examined in this article, as well as the two authors' references to both Greco-Roman and the biblical tradition point to the fact that the myth of the "Golden age", as discussed in this article, should be envisaged as a variant of the universal "Myth of origins", which encompasses among its other avatars the Christian Eden, rather then a direct reference to the antique myth originating in Hesiod. The expression itself occurs in Bougainville's text with regard to the sexual liberation of Tahitian girls: "those countries where the ease of golden age is still in use", $\underline{A}$ Voyage around the world, performed by order of His most Christian majesty, In the years 1766, 1767, 1768 and 1769 by Lewis de Bougainville, Colonel of Foot, and Commodore of the Expedition, in the Frigate La Boudeuse, and the Store-ship L'Etoile, translated from the French by John Reinhold Forster (London: J. Nourse and T. Davies, 1772), 218.

${ }^{v}$ References to the Garden of Eden are explicit in both texts. Bernardin de Saint-Pierre describes the youth of his two protagonists as follows: "They were in the morning of life and had all its freshness: so must our first parents have appeared in the garden of Eden when, coming from the hands of God, they saw each other and drew near and talked for the first time as brother and sister; Virginia, modest, trusting and mild like Eve, and Paul, another Adam, having the stature of a man and the simplicity of a child”, Paul and Virginia, translated from the French and with an Introduction by John Donovan (London and Boston: Peter Owen, 1982), 72. Bougainville, on the other hand, notes of his visit to the interior of Tahiti: "I thought I was transported to the Garden of Eden” (Bougainville, 1772, 228).

vi This novel is "a relaxation from my Studies of Nature, and the application that I made of its laws to the happiness of two unfortunate families”, Préambule [1806], (PV, 1982, 21). 
${ }^{\text {vii }}$ Whilst Bernardin was himself a close friend and follower of Rousseau in the 1770s (not always taking his master's postulates for granted nevertheless), Bougainville’s familiarity with Rousseau's philosophical opus is obvious, yet somewhat problematic, as it may have been based on a simplifying misinterpretation of the philosopher's theses according to Robert Mauzi, "Représentation du paradis sous les tropiques ", L’Importance de l'exploration maritime au siècle des lumières à propos du voyage de Bougainville, M. Mollat et E. Taillemite, eds. (Paris : CNRS, 1978), 169-75.

viii Avis sur cette édition [1789], in Bernardin de Saint-Pierre, Paul et Virginie (Paris: Bordas, « Classiques Garnier »,1989), CLVII.

${ }^{\text {ix }}$ Cf Jean-Michel Racault's analysis of this passage in 'Virginie entre la nature et la vertu. Cohésion narrative et contradictions idéologiques dans Paul et Virginie’, Dix-huitième siècle 18 (1986) : 389-404.

${ }^{x}$ After Virginia's tragic death in a shipwreck, Paul pines away and dies, followed by his and Virginia's mother and their domestic servants. The only remaining (associate) member of the micro-community is the old hermit who survives to tell the tale.

${ }^{x i}$ Malcolm Cook: "Bougainville and one noble savage: two manuscript texts of Bernardin de Saint-Pierre”, Modern Language Review 89 (1994): 842-55.

${ }^{\text {xii }}$ For a more detailed account of Commerson's stay on Mauritius under Poivre see Grove, 1995 and Pasfield Oliver, S. The Life of Philibert Commerson, (London: Murray, 1909).

xiii Yves Girard, who has studied the genealogy of the Tahitian Utopia, concludes: «Bougainville's travelogue had the effect of revealing old myths and instinctive impulses, making them re-emerge, and reviving them ; the elements it provided reappeared in widely varying contexts, at a period when controversy regarding the state of nature tended to be resolved by or disappear in abstract systematizations. Impressionist readings and a reaction of sentimental, impulsive attraction to the Tahitian mirage were succeeded by controversial uses 
of it, half-lyrical, half-satirical philosophical exhortations, and romantic artifices and intrigues which served as a pretext for the criticism of mores and society. ", « De l'exploration à l’Utopie », French Studies 31 (1977) : 26-41, 40 (Translation mine).

xiv One of the most telling indicators of this semantic merging between the exotic and the erotic is the American English idiom "exotic dancer" readily identified as a "striptease dancer” in dictionary entries on both sides of the Atlantic.

${ }^{x v}$ Gérard de Nerval, Lorely, Sensations d’un voyage enthousiaste - I Du Rhin au Mein (18381840). Introduction; Euvres complètes de Gérard de Nerval (Paris : Michel Lévy frères, 1867), 3:439 (Translation mine).

${ }^{\text {xvi }}$ Examining the reception and enormous success of Paul et Virginie extending throughout the nineteenth century, John Donovan concludes: "It functioned, evidently, as a referencepoint and imaginative node for ideas of primitivism, childhood love, natural education and sexual innocence, and, as such, exercised an unusually rich and varied influence on literary creation”, (PV, 1982, Introduction, 10).

${ }^{\text {xvii }}$ Lee Wallace also identifies Bougainville’s account, or rather its reception as the source of a long literary tradition: “The Enlightenment reception of Louis Antoine de Bougainville’s account of Tahiti inaugurates a long tradition of literary representation and ethnographic scholarship within which the Pacific appears as the domain of unchecked heterosexual gratification such that the paradigmatic Pacific encounter between imperial agent and indigenous Polynesian subject is a sexualized one.” (1). The question of sources for the eroticized image of the South Seas is however more complex, if we extend our consideration beyond the French realm. Hawkesworth's account of James Cook's circumnavigation, published not long after Bougainville’s travelogue, had a considerable impact in the Englishspeaking world. One of the erotic Tahitian episodes which attracted particular public attention and scandal was the "Point Venus Scene". For an overview of its posterity and influence see 
Neil Rennie's article "The Point Venus 'Scene' ", Science and exploration in the Pacific. European Voyages to the Southern Oceans in the Eighteenth Century, edited by Margarette Lincoln (Rochester: Boydell Press, 2001), 135-46.

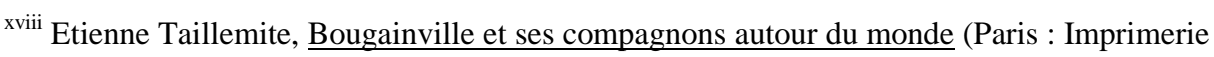
nationale, 1978).

${ }^{\text {xix }}$ Louis de Bougainville's Pacific Journal, translated and edited by John Dunmore (London : The Hakluyt Society, 2002).

${ }^{\mathrm{xx}}$ Louis-Antoine de Bougainville, Voyage autour du Monde, Choix, preface et "Les clés de l’oeuve” par Pierre Mounier. (Paris: Pocket, 1999), 120.

${ }^{\text {xxi }}$ Bernardin de Saint-Pierre, Voyage à l’Ile de France, Un officier du roi à l'île Maurice 1768-1770 (Paris : La Découverte/Maspero, 1983), 254.

xxii Jacques-Henri Bernardin de Saint-Pierre: Journey to Mauritius. Translated with an Introduction and notes by Jason Wilson. (Oxford: Signal Books, 2003), 229.

xxiii Bernardin's intention is clearly stated in his Preface to the 1788 Edition: "I wrote this little book with great aims in view. In it I have tried to paint a soil and a vegetation different from those of Europe. Our poets have for long enough made their lovers rest on banks of streams, in meadows and beneath the leaves of beeches. Mine were to sit on the seashore, at the foot of high rocks in the shade of coconut-palms, banana-trees and lemon-trees in flower. The other part of the world wants only Theocrituses and Virgils to provide us with pictures at least as worthy of interest as those of our own country”, (PV, 1982, 37, emphasis mine).

xxiv Cf Jean-Michel Racault, «Système de la toponymie et organisation de l'espace romanesque dans Paul et Virginie ", Studies on Voltaire and the Eighteenth Century 242 (1986) : 377-419.

${ }^{\mathrm{xxv}}$ Curtius notes of this topos "It is, as we saw, a beautiful, shaded natural site. Its minimum ingredients comprise a tree (or several trees), a meadow, and a spring or brook. Birdsong and 
flowers may be added. The most elaborate examples also add a breeze”, European Literature and the Latin Middle Ages, translated from the German by Willard R. Trask (New York: Pantheon books, 1953), 195.

xxvi «The badamier seems to have been made to give shade. It rises like a beautiful pyramid, made of several well-separated levels. One could build charming cabinets between each floor; the leaves are beautiful. It gives almonds that taste rather good.», (Journey to Mauritius, 140)

${ }^{\text {xxvii }}$ It possible, of course, to argue that providentialism is a product of Northern or Western civilisation, which forces its frame of reference upon its exotic object, but this dimension of Bernardin's work can and has been easily abstracted, as we shall try to demonstrate.

xxviii Derived from State Library of NSW Transcription of Banks's Journal page (vol. 2) 348, February 2004 (The Endeavour Journal of Joseph Banks, 1768-1771). The original spelling has been preserved throughout.

${ }^{\text {xxix }}$ It should be mentioned that Banks was the Royal Society's representative on the voyage and was therefore less bound by naval protocol, which granted him greater liberty in interaction with the encountered populations, but also greater stylistic liberties with regard to the ship’s log genre.

${ }^{\mathrm{xxx}}$ To illustrate the extent of this tendency, it suffices to mention that the English translator of the travelogue, John Reinhold Forster, evinces an effort to “rectify" Bougainville’s misconceptions, by adding personal comments in footnotes to the original text. Aotourou's credibility is, for instance, completely undermined in the following note: “Though our author has strongly pleaded in this paragraph in behalf of Aotourou, it cannot, however, be denied that he was one of the most stupid fellows; which not only has been found by Englishmen who saw him at Paris, during his stay there, and whose testimony would be decisive with the public, were I at liberty to name them, but the very countrymen of Aotourou were without 
exception all of the same opinion, that he had very moderate parts, if any at all” (n.265). In a different footnote, Forster rejects Bougainville's description of the Tahitian language, imputing it anew to the inadequacy of his source: “ it is therefore highly probable Mr. de B. picked up his vocabulary of words from Aotourou who had an impediment in his speech” (n. 272).

xxxi Baudelaire's poem Parfum exotique conveys, for instance, an exotic reverie of an unnamed tropical island, heavily influenced by the Bougainvillean Tahiti: ‘Une île paresseuse où la nature donne/Des arbres singuliers et des fruits savoureux;/Des hommes dont le corps est mince et vigoureux/Et des femmes dont l'œil par sa franchise étonne.' Charles Baudelaire, Les Fleurs du mal (Paris : Gallimard, 1996), 57.

xxxii Northrop Frye, “Historical Criticism: Theory of Modes” in Anatomy of Criticism [1957] (London: Penguin Books, 1990), 31-67.

xxxiii It is, indeed, reasonable to claim that half the charm of James Bond adventures, for instance, would be lost without these two elements. For a more detailed account of this tendency see Jean-Marc Moura, L’Image du tiers monde dans le roman français contemporain (Paris : PUF, 1992). 